\title{
Combined oral toxicity of azaspiracid-1 and yessotoxin in female NMRI mice
}

\author{
John A.B. Aasen ${ }^{\mathrm{a},{ }^{*}}$, Arild Espenes ${ }^{\mathrm{b}}$, Christopher O. Miles ${ }^{\mathrm{c}, \mathrm{d}}$, Ingunn A. Samdal ${ }^{\mathrm{c}}$, Philipp Hess ${ }^{\mathrm{e}, \mathrm{f}}$ and \\ Tore Aune
}

\author{
${ }^{a}$ Norwegian School of Veterinary Science, Department of Food Safety and Infection Biology, P.O. Box \\ 8146 Dep., 0033 Oslo, Norway \\ ${ }^{\mathrm{b}}$ Norwegian School of Veterinary Science, Department of Basic Sciences and Aquatic Medicine, P.O. \\ Box 8146 Dep., 0033 Oslo, Norway \\ ${ }^{c}$ Norwegian Veterinary Institute, P.O. Box 750 Sentrum, NO-0106 Oslo, Norway \\ ${ }^{\mathrm{d}}$ AgResearch Ltd, Ruakura Research Centre, Private Bag 3123, Hamilton 3240, New Zealand \\ ${ }^{\mathrm{e}}$ Marine Institute, Renville, Oranmore, Co. Galway, Ireland \\ ${ }^{\dagger}$ IFREMER, Department of Environment, Microbiology \& Phycotoxins, Rue de l'Île d'Yeu, 44311 \\ Nantes Cedex 03, France
}

* Corresponding author: John A.B. Aasen, Tel.: +47 22597024; fax: +47 22964634, email address : john.aasen@nvh.no

\begin{abstract}
:
For many years, the presence of yessotoxins (YTXs) in shellfish has contributed to the outcome of the traditional mouse bioassay and has on many occasions caused closure of shellfisheries. Since YTXs do not appear to cause diarrhoea in man and exert low oral toxicity in animal experiments, it has been suggested that they should be removed from regulation. Before doing so, it is important to determine whether the oral toxicity of YTXs is enhanced when present together with shellfish toxins known to cause damage to the gastrointestinal tract. Consequently, mice were given high doses of YTX, at 1 or $5 \mathrm{mg} / \mathrm{kg}$ body weight, either alone or together with azaspiracid-1 (AZA1) at $200 \mu \mathrm{g} / \mathrm{kg}$. The latter has been shown to induce damage to the small intestine at this level. The combined exposure caused no clinical effects, and no pathological changes were observed in internal organs. These results correspond well with the very low levels of YTX detected in internal organs by means of LC-MS/MS and ELISA after dosing. Indeed, the very low absorption of YTX when given alone remained largely unchanged when YTX was administered in combination with AZA1. Thus, the oral toxicity of YTX is not enhanced in the presence of sub-lethal levels of AZA1.
\end{abstract}

Keywords: Azaspiracid-1; AZA1; Yessotoxin; YTX; Marine algal toxins; Absorption; Pathology; Sublethal; NMRI; Mice; LC-MS/MS; oral toxicity 


\section{Introduction}

The presence of yessotoxin (YTX), a disulphated polycyclic ether toxin, was first reported in scallops (Patinopecten yessoensis) in 1987 (Murata et al., 1987). The toxin was then found together with okadaic acid group toxins (OA/DTXs) that are well known for causing diarrhetic shellfish poisoning (DSP) in man (Yasumoto et al., 1978). YTX and its analogues (YTXs) are produced by the dinoflagellate algae Protoceratium reticulatum (Satake et al., 1997; Satake et al., 1999; Ciminiello et al., 2003; Samdal et al., 2004), Lingulodinium polyedrum (Draisci et al., 1999) and Gonyaulax spinifera (Rhodes et al., 2006). In recent years, YTXs have been reported in shellfish from many countries, including Japan, New Zealand, Australia, Canada, Italy, France, Norway and the United Kingdom (FAO/IOC/WHO, 2004; Amzil et al., 2008). YTXs may contribute significantly to the outcome of the traditional mouse bioassay for DSP toxins when injected intraperitoneally (i.p.). However, the mechanisms of action of OA/DTXs and YTXs are different, since it has been found that YTXs, in contrast to OA/DTXs, do not inhibit protein phosphatases (Ogino et al., 1997). The only pathological changes observed upon i.p. injection of YTXs is in the heart muscle (Aune et al., 2002; Tubaro et al., 2003) and no diarrhetic effect is observed after either i.p. or oral administration (Aune et al., 2002; Tubaro et al., 2003; Tubaro et al., 2004).

The lack of documented cases of human poisoning with YTX is consistent with the very low acute oral toxicity of YTX generally demonstrated in experimental animals (Ogino et al., 1997; Aune et al., 2002; Tubaro et al., 2003; Paz et al., 2008; Munday et al., 2008; Tubaro et al., 2008), although varying results have been obtained with respect to the effect on the heart muscle, studied by electron microscopy, after repeated oral exposure to YTX. In one study, mice given $5 \mathrm{mg} / \mathrm{kg}$ YTX by gavage seven times in three weeks did not show adverse effects (Espenes et al., 2006) whereas, in a separate study, mice given $1 \mathrm{mg} / \mathrm{kg}$ YTX daily for one week showed changes in cardiac muscle $24 \mathrm{~h}$ and $30 \mathrm{~d}$ after the last treatment (Tubaro et al., 2008).

The very low oral toxicity of YTX has prompted discussion as to whether the YTXs should be deregulated in the $\mathrm{EU}$, and in a recent recommendation from the European Food Safety Authority (EFSA, 2008), an acute reference dose for YTX of $25 \mu \mathrm{g} / \mathrm{kg}$ was suggested, based on the no-observed-adverse effect level (NOAEL) of $5 \mathrm{mg} / \mathrm{kg}$. Depending on the consumption of contaminated shellfish, the derived maximum acceptable level of YTX in shellfish will vary between $3.75 \mathrm{mg} / \mathrm{kg}$ (400 g portion) and $15 \mathrm{mg} / \mathrm{kg}$ (100 g portion). This recommendation is in strong contrast to today's EU regulatory level of $1 \mathrm{mg} / \mathrm{kg}$ YTXequivalents in shellfish meat.

Before YTXs are considered for deregulation, it is important to know whether their low oral toxicity might be enhanced by simultaneous presence of shellfish toxins acting on the gastrointestinal tract, for example azaspiracids (AZAs) and OA/DTXs. Both the AZAs and the OA/DTXs cause damage to the small intestine (Terao et al., 1986; Ito and Terao, 1994; Ito et al., 2000; Ito et al., 2002a; Ito et al., 2002b). The main effect of AZAs in humans is severe diarrhoea, together with nausea, vomiting and abdominal cramps, similar to the symptoms of DSP (McMahon and Silke, 1996). However, unlike OA/DTXs, AZAs do not inhibit protein phosphatases (Twiner et al., 2005). The AZAs affect the cytoskeleton (Roman et al., 2002), and studies have shown that AZAs are able to disrupt the paracellular barrier in cells in the GI-tract, thus increasing fluid secretion (Ryan et al., 2006).

Both YTXs and AZAs has been observed in shellfish from the same locations in several countries (Twiner et al., 2008; Amzil et al., 2008; Ueoka et al., 2009; Hess, 2010) including Norway (Norwegian National Surveillance Program 2000-2010, unpublished data). Thus, an experiment was set up to study whether combined oral exposure (by gavage) of mice with AZA1 and YTX would lead to increased uptake of either toxin, or to more severe toxic effects in the heart or other internal organs compared to the effects caused by each toxin alone. 


\section{Materials and Methods}

Toxins: AZA1 used in this study was an aliquot of the certified AZA1-stock produced in 2006, namely lot 2006/07/19 of NRC CRM-AZA1 (NRC-CNRC, 2007). The aliquot had been set aside after NMR-characterization of the whole lot and was stored in methanol at $-80^{\circ} \mathrm{C}$, a condition under which no degradation of AZA1 was observed during a 12-month stability study (Perez et al., 2010). The isolation procedure has been briefly described by Ronzitti et al. (2007). Gravimetry, LC-MS and NMR have been used in the certification of the purified AZA1, and the certification process and uncertainties are described elsewhere (Perez et al., 2010). The purified toxin, provided in ampoulled aliquots of $40.7 \mu \mathrm{g} / \mathrm{mL}$ in methanol, was used as a stock solution. Some impurities were identified at concentrations ranging from 0.4 to $2.8 \%$, relative to AZA1. The major impurity (2.8\%) was an isomer of AZA1, while AZA3 and dehydro-AZA3 were present at 0.4 and $0.7 \%$, respectively. YTX was purified and stored in methanol solution to prevent decomposition as described by Loader et al. (2007). The purity of this material was estimated to be $>95 \%$ from NMR analysis (see supporting information from Loader et al. (2007)) and its concentration was determined by LC-MS/MS analysis relative to a certified standard of YTX from NRC (NRC-CNRC, 2006).

Other chemicals: Ethanol (96\%, from Arcus, Norway), methanol and acetonitrile (HiperSolve, BDH Prolabo, VWR), formic acid (pro analysis, Merck, Germany) and ammonium formate (pro analysis, Carl Roth, Karlsruhe, Germany) were obtained from VWR, Norway. Saline solution $(0.9 \%)$ was prepared at the Norwegian School of Veterinary Science. Deionised water (grade I) from a Milli-Q system (Millipore, MA, USA) was used in all preparations requiring aqueous solutions.

Animals: Female NMRI mice, weighing between 19 and $22.5 \mathrm{~g}$ were used. The NMRI mouse is a Swiss mouse strain, originating from Lynch, and obtained by the Naval Medical Research Institute, USA (NMRI). It was established at M\&B A/S (now Taconic Europe, Bomholt, Denmark), in 1961 and again in 1985, where it is maintained as an outbred stock. The mice had access to feed and water ad libitum. Day-length (12/12), temperature (20-22 degrees $\mathrm{C}$ ) and humidity was monitored. An ethical permit was obtained for the animal trials from the Norwegian Animal Research Committee.

Solutions for study of combined toxicity of AZA1 and YTX: Two $500 \mu \mathrm{g}$ aliquots of YTX in $\mathrm{MeOH}$ were combined and the solvent was evaporated under nitrogen to give a white solid. This was re-dissolved immediately in $\mathrm{MeOH}$ to give $2000 \mu \mathrm{g} / \mathrm{mL}$ as a stock solution. The calculated volumes (Table 1 ) of the YTX stock solutions were dispensed into vials, which were capped and stored at $-20{ }^{\circ} \mathrm{C}$ until required for preparation of doses. Immediately prior to dosing, the YTX solutions were evaporated to dryness (gentle stream of nitrogen at ca 35 $\left.{ }^{\circ} \mathrm{C}\right)$. Then AZA1 stock (395 $\left.\mu \mathrm{L}\right)$ was added as appropriate. The contents of all vials were evaporated to dryness under nitrogen and dissolved in $40 \mu \mathrm{L}$ of $96 \% \mathrm{EtOH}$ (vortex mixer) whereupon $960 \mu \mathrm{L}$ saline was added with vortex-mixing. The clear colourless solutions were then taken directly to the animal facility and used in the dosing experiment. Volumetric transfers of toxin solutions and solvents were performed with $500 \mu \mathrm{L}$ or $100 \mu \mathrm{L}$ Hamilton syringes. Saline was dispensed with a $1 \mathrm{~mL}$ air-displacement pipette (Finnpipette).

\section{Animal experiments:}

Yessotoxin was given by gavage at 1 or $5 \mathrm{mg} / \mathrm{kg}$, either alone or in combination with AZA1 at $200 \mu \mathrm{g} / \mathrm{kg}$. A fifth group of mice received $200 \mu \mathrm{g} / \mathrm{kg}$ AZA1 alone while a group of control mice were given vehicle only. Each mouse was dosed a volume of $250 \mu \mathrm{L}$ per $20 \mathrm{~g} \mathrm{b.w}$. The groups consisted of three mice except the control group which consisted of six mice. All mice were sacrificed after $24 \mathrm{~h}$.

The mice were killed by cervical dislocation. Tissue samples were immediately taken from brain, heart muscle, lungs, thymus, liver, spleen, kidneys, stomach, small intestine (duodenum, middle and lower jejunum) and colon for fixation in formalin. One half of the brain was fixed in toto and cut in three transverse sections through the level of frontal cortex, 
midbrain and cerebellum. All the fixed tissues were dehydrated, embedded in paraffin wax, and sections were stained with haematoxylin and eosin. For analysis of AZA1 and YTX, blood (from large blood vessels in thoracic cavity) and samples from the tissues mentioned above were collected and frozen. For electron microscopy, two pieces of tissue from the heart muscle less than $1 \mathrm{~mm}$ in diameter were fixed in $3 \%$ glutaraldehyde in $0.1 \mathrm{M}$ cacodylate buffer, treated with $\mathrm{OsO}_{4}$ and embedded in Epon. Ultrathin sections from each embedded tissue block were stained with uranyl acetate and lead citrate and examined in a Philips EM208S electron microscope.

All the tissue samples from stomach and intestines for ELISA and LC-MS/MS analysis had the digestive contents removed mechanically before they were homogenised and extracted.

\section{Chemical analyses:}

Extraction: Samples of tissues were pooled all 3 animals in each group of mice receiving AZA1 and YTX, and 4 of 6 controls. Pooled samples of the organs in each group were transferred to capped pre-weighed $15-\mathrm{mL}$ polypropylene centrifuge tubes (NUNC A/S, Roskilde, Denmark), weighed, and stored at $-80^{\circ} \mathrm{C}$ until analysis. The tissues ( $0.5 \mathrm{~g}$ portion of pooled liver homogenate and $0.1-0.6 \mathrm{~g}$ of pooled tissue from the other organs) were homogenized in $2.0 \mathrm{~mL} \mathrm{MeOH}$ with water bath cooling using an Ultra-turrax ${ }^{\circledR}$ (Ika, Germany) at $15,000 \mathrm{rpm}$ for $30-60 \mathrm{~s}$. The homogenised samples were centrifuged at $\sim 1500 \mathrm{~g}$ for 20 min, left in the refrigerator overnight and then centrifuged again at $\sim 1500 \mathrm{~g}$ for $20 \mathrm{~min}$ the following day. Aliquots of supernatants were transferred to HPLC vials for analysis, and the remainder stored in capped vials at $-80^{\circ} \mathrm{C}$ for later study (ELISA).

LC-MS/MS: Analysis was performed on an LC-MS/MS system consisting of an Agilent 1200 HPLC system connected to an Agilent G6410 MS/MS (Santa Clara, CA, USA). The column used was a Hypersil BDS C8 $(3.5 \mu \mathrm{m}, 2.0 \times 50 \mathrm{~mm})$ (Thermo Fisher Scientific, Waltham, MA, USA). A gradient elution was run with two mobile phases; water (A) and $95 \%$ acetonitrile (B), each containing $50 \mathrm{mM}$ formic acid and $2 \mathrm{mM}$ ammonium formate (Table 2), based on Quilliam et al. (2001). The AZA1 and YTX used for dosing were analysed by selected reaction monitoring (SRM) for the transitions characteristic for AZA1, AZA2 and AZA3 $(\mathrm{m} / \mathrm{z}$ 842.5, 856.5 and $828.5 \rightarrow 362.5)$ and YTX, 45-hydroxyYTX and carboxyYTX $(\mathrm{m} / \mathrm{z} 1141.5$, 1157.5 and $1173.5 \rightarrow 855.5)$. The samples were quantified against standards for AZA1 and YTX from the CRM program of IMB, NRC, Halifax, NS, Canada.

ELISA: Sample preparation: Extracts for ELISA analysis were prepared by serial three-fold dilutions with phosphate-buffered saline with $0.05 \%$ Tween 20 (PBST) and sample buffer (10\% methanol in PBST) to give a final methanol concentration of $10 \%$. ELISA quantitation was performed at three dilutions out of 1:10, 1:30, 1:90, 1:270, 1:810 and 1:2430 (usually 1:10, 1:30, 1:90 or 1:270), as appropriate.

Reagents: ELISA analysis (Briggs et al., 2004) was performed with a quantitative YTX standard obtained by dilution of the dosing solution and calibrated by LCMS against the certified NRC standard. Ovine antibodies to YTXs (serum \#505) were obtained from AgResearch Ltd, Hamilton, New Zealand (Briggs and Miles, 1999; Briggs et al., 2004). Horseradish peroxidase (HRP)-coupled rabbit anti-sheep antibodies were purchased from Zymed Laboratories (61-8620; now distributed by Invitrogen, Camarillo, CA, USA). Substrate was K-Blue ${ }^{\circledR}$ Aqueous Substrate (TMB) from Neogen (Lexington, USA). OVA-BrYTX-coater was prepared as described by Briggs et al. (2004) and all other reagents for the YTX-ELISA were prepared according to Samdal et al. (2004).

ELISA analysis: The concentration of YTXs in each mouse tissue sample extract was determined by indirect competitive ELISA as described by Briggs et al. (2004), with only minor adjustments to plate coater and antibody concentrations to optimize the assay (Samdal et al., 2004). All incubations were performed at room temperature. YTX standard in methanol $(1 \mu \mathrm{g} / \mathrm{mL})$ was diluted in PBST and sample-buffer (10\% methanol in PBST), to give a methanol concentration of $10 \%$. Serial three-fold dilutions of the YTX standard were performed with sample buffer, giving 10 standards from $0.002-40 \mathrm{ng} / \mathrm{ml}$. Serial dilutions of 
standards and samples were performed in duplicate. Absorbances were measured at 450 $\mathrm{nm}$ using a plate reader (Wallac 1420 Victor $^{2}$ multilabel counter, Wallac, Turku, Finland).

\section{Results}

Very low levels of YTX were found in internal organs when mice were given YTX by gavage at 1 or $5 \mathrm{mg} / \mathrm{kg}$ (Fig. 1, Table 3). The level of quantification for YTX was exceeded only in kidneys, spleen, liver and lungs. Considerably higher levels of YTX were recovered from tissue samples from the GI tract. When mice were exposed to combinations of either 1 or 5 $\mathrm{mg} / \mathrm{kg}$ YTX together with AZA1 at $200 \mu \mathrm{g} / \mathrm{kg}$, the level of YTX in internal organs remained very low (Fig. 2, Table 3). In Fig. 2, only data from AZA1 together with the highest YTX dose are given, due to the very low levels of YTX at $1 \mathrm{mg} / \mathrm{kg}$. A very large increase in YTX-levels was observed in stomach tissue when YTX, at both levels, was combined with AZA1, whereas the levels found in the small and large intestines were similar to the levels when YTX was given alone.

An estimate of the total amount of YTX detected by LCMS in different internal organs $24 \mathrm{~h}$ after gavage is shown in Table 4 . When given alone, the amount of YTX recovered from each internal organ was below $0.05 \%$ of the total amount given, regardless of the YTX dose given. The amount of YTX in the heart and brain were below the limit of quantification. When co-administered with AZA1 $(200 \mu \mathrm{g} / \mathrm{kg})$, the levels of YTX in organs remained essentially unchanged (Table 4).

The effect of the combination of YTX with AZA1 was also studied concerning effects on absorption of AZA1 from the GI-tract (Fig. 3). The absorption of AZA1 was considerably higher than that of YTX. Co-administration with YTX did not enhance the absorption of AZA1. Analyses of YTX were performed both with LC-MS and ELISA, since only YTX and main analogues are quantified by the LC-MS, while a whole range of analogues/metabolites are detected by ELISA (Aasen et al. 2005, Briggs et al., 2004; Samdal et al., 2005). Results of both methods corresponded well to each other in samples from the GI tract, whereas the YTX levels in internal organs were consistently higher by ELISA than by LC-MS (Table 3 and Supporting Information). However, YTX levels in internal organs were very low, increasing the uncertainty in both methods. Nevertheless, the correlation between the two methods for the different tissues was examined using linear regression. The correlation ratios were 1.1 $\left(R^{2}\right.$ 0.999) for the stomach, $1.4\left(R^{2} 0.99\right)$ for the duodenum, $1.2\left(R^{2} 0.94\right)$ for the jejunum, 1.5 $\left(R^{2} 0.97\right)$ for the ileum, and $1.9\left(R^{2} 0.94\right)$, suggesting a low level of metabolism during passage through the $\mathrm{Gl}$ tract. The correlation ratios for internal organs were $1.3\left(R^{2} 0.89\right)$ for lung, $2.2\left(R^{2} 0.85\right)$ for spleen, $1.6\left(R^{2} 0.74\right)$, and $3.8\left(R^{2} 0.90\right)$ for kidney. These results suggest a degree of metabolism of YTX within the internal organs of the mouse.

The mice were observed for $24 \mathrm{~h}$, and no clinical signs of disease were observed for the period, either for those exposed to AZA1 or YTX alone or for those exposed to the combination of the two compounds.

Macroscopical pathology: Mice that had received AZA1 alone showed considerable retention of material in the stomach and the upper $1 / 3$ of the small intestine was dilated with increased fluidity of the content compared with control animals. Mice that received a combination of YTX and AZA1 showed similar changes to those that had received AZA1 only, at both 1 and $5 \mathrm{mg} / \mathrm{kg}$ YTX. In mice that had received only YTX at 1 and $5 \mathrm{mg} / \mathrm{kg}$, no changes were observed compared to the control mice.

Microscopical pathology: In mice that had received YTX at 1 or $5 \mathrm{mg} / \mathrm{kg}$ in combination with AZA1 at $200 \mu \mathrm{g} / \mathrm{kg}$, the villi in the duodenum appeared contracted, blunt and occasionally club-shaped, the cryptal compartments were extended and an extensive infiltration of polymorphonuclear granulocytes (neutrophils) were noted in the lamina propria. These changes were similar to the changes observed in the duodenum of mice that had received AZA1 alone (Fig. 4). In mice that had been given YTX alone, the duodenum was normal and 
similar to the duodenum in control mice. By light microscopy, no changes were observed in any of the other organs examined including the other intestinal segments.

By electron microscopy, no changes were found in the heart muscle, either in the group given a combination of AZA1 and YTX or in the group given YTX alone. The myocardial cells surrounding the capillaries showed no signs of cytoplasmic swelling or abnormal mitochondria (Fig. 5) and the general structure of the myofibrils and distribution and structure of the mitochondria were found normal (Fig. 6).

\section{Discussion}

The present study examined the effect of oral exposure of mice to the marine algal toxins AZA1 and YTX and combinations thereof. Such co-exposure could potentially have led to new or enhanced toxic effects that are not observed when the toxins are administered separately. In particular, we wondered if the pathological changes caused by AZA1 in the intestine (Ito et al., 2000; Ito et al., 2002b; Aasen et al., 2010) could damage the mucosal barrier and increase the absorption of YTX, and thereby cause systemic effects similar to those observed after intraperitoneal (i.p.) injection of YTX (Terao et al., 1990; Aune et al., 2002; Tubaro et al., 2003). Very low concentrations of YTX were measured in kidneys, spleen, liver and lungs, when YTX at 1 or $5 \mathrm{mg} / \mathrm{kg}$ was given alone (Fig. 1, Table 3). In blood, the YTX level was below the LOQ by LC-MS in all groups except in the group given YTX at $5 \mathrm{mg} / \mathrm{kg}$ together with AZA1, where the YTX level was very low. When using ELISA, the YTX concentration in blood was slightly higher, and corresponded well with the results reported by Tubaro et al. (2008).

The level of YTX in the heart, the putative target organ when YTX is given i.p., was below the level of quantification by LC-MS. This corresponds well with previous data showing no significant difference between mice exposed to YTX and controls after repeated oral exposures, i.e. a dose of up to $5 \mathrm{mg} / \mathrm{kg}$ YTX given seven times during three weeks (Espenes et al., 2006). However, other studies have indicated that YTX can induce ultrastructural changes in the heart muscle of mice both after short term exposure (Aune et al., 2002) and after repeated daily exposures of $1 \mathrm{or} 2 \mathrm{mg} / \mathrm{kg}$ for one week (Tubaro et al., 2004; Callegari et al., 2006; Tubaro et al., 2008). In the present study, the YTX levels in internal organs were very low, suggesting that only a small proportion of YTX is transported across the intestinal barrier. However, only one time point and a limited number of organs were analysed, so detailed information on the absorption and distribution of YTX could not be obtained. The total fraction of YTX in the internal organs measured by LC/MS accounted for less than $0.1 \%$ of the administered dose (Table 4). Most of the toxin presumably passed through the animals since most of the YTX was recovered from the lower intestine and the faeces, while only trace amounts were found in blood, urine and tissues. (Munday et al., unpublished results).

The level of YTX in the stomach was around two orders of magnitude higher when YTX was given in combination with AZA1, compared to when YTX was given alone (Table 3). Since the stomach content was only mechanically removed before the toxin level was measured, a sharp distinction between toxin level in the content and the stomach wall could not be made.

The observed increase in retention of the stomach contents, suggest an inhibitory effect of AZA1 on the motility of the stomach and duodenum, which would extend the period with high YTX levels in the stomach. Another possible explanation is that the combination induced absorption of YTX into the stomach wall, but this is less likely since such an absorption ought to have resulted in higher toxin levels in the liver and/or other internal organs. However, since the YTX concentration in the distal parts of the intestines was similar to when YTX was given alone (Table 3 and Fig. 2), it seems that the motility of the stomach and intestines is not severely inhibited due to AZA1 but rather slowed. It may be assumed that the part of the intestine with pathological changes has been exposed to a substantial amount of YTX. 
The concentrations of AZA1 found in the different tissues when given in combination with YTX were similar to the levels when AZA1 was given alone at $200 \mu \mathrm{g} / \mathrm{kg}$ (Fig. 3). These results were also similar to those obtained in Aasen et al. (2010) for AZA1 at $200 \mu \mathrm{g} / \mathrm{kg}$. Consequently, YTX does not seem to influence the absorption of AZA1.

In mice exposed to a combination of AZA1 and YTX, the pathological changes in the intestine were similar to the changes caused by AZA1 alone. The damage to the intestine did not appear to increase the absorption of YTX as shown by the quantification of YTX in blood and internal organs by LC-MS. The levels found in the blood by LC-MS and ELISA (Table 3 ) corresponded with the levels reported by Tubaro et al., (2008). The low YTX levels in the internal organs were consistent with the histological investigations by light microscopy showing normal morphology in the same organs.

It is possible that the YTX concentration in internal organs could have been higher at a time point earlier than $24 \mathrm{~h}$, or that YTX could have been modified in the tissues to analogues not detectable by the LC-MS method. However, lack of pathological changes strongly indicates that a high YTX concentration in the tissues had not been present during the first $24 \mathrm{~h}$ as this has been shown to be within the time limit to induce changes in tissues (Aune et al., 2002; Tubaro et al., 2003). The ELISA measurement of YTXs did not show the presence of a high proportion of analogues in most tissues, supporting the LC-MS data obtained in the present study but indicating the potential for a degree of metabolism in internal organs of mice.

To more precisely address possible changes in the presumed target organ for YTX, the heart muscle, ultrastructural studies were performed. As early as 1990, Terao et al. reported the toxic effects of YTX upon i.p. exposure of mice. The animals died within a few hours at doses of $300 \mu \mathrm{g} / \mathrm{kg}$. Subsequent studies have confirmed the high lethality of YTX when given via the i.p. route (Terao et al., 1990; Ogino et al., 1997; Aune et al., 2002; Tubaro et al., 2003; Aune et al., 2008). YTX given i.p. caused changes in the cardiac muscle with oedema and vacuolation (Aune et al., 2002). The degree of damage to the heart has varied in different studies. Terao et al. (1990) reported swelling and degeneration of the endothelial lining cells of the left ventricle and swelling of most cardiac muscle cells at $500 \mu \mathrm{g} / \mathrm{kg}$ of YTX when given i.p., and Aune et al. (2002) reported less severe changes in the heart after i.p. doses of 1,000 $\mu \mathrm{g} / \mathrm{kg}$ one $\mathrm{hr}$ after injection, with swelling and separation of myofibrils and mitochondria of myocardial cells in the left ventricle, most pronounced near the capillaries.

The effects of oral exposure have been more variable, as Terao et al. (1990) found no effects on the heart $21 \mathrm{~h}$ after exposure to YTX at $0.5 \mathrm{mg} / \mathrm{kg}$ whereas Aune et al. (2002) described such changes in mice $24 \mathrm{~h}$ after oral dosing with 7.5 and $10 \mathrm{mg} / \mathrm{kg}$ and $1 \mathrm{~h}$ after dosing of $2.5,5$ and $10 \mathrm{mg} / \mathrm{kg}$, although in the latter group the changes were moderate for the lowest dose. Even doses of 1 and $2 \mathrm{mg} / \mathrm{kg}$ YTX given orally have been reported to induce ultrastructural changes in heart muscle cells $24 \mathrm{~h}$ after adminstration although no signs of toxicity and no indication of cardiac tissue damage based on plasma enzyme measurements, were noted (Tubaro et al., 2003). In the present study, no ultrastructural changes were seen in the heart muscle $24 \mathrm{~h}$ after 1 or $5 \mathrm{mg} / \mathrm{kg}$ of YTX, either alone or in combination with AZA1, findings that were consistent with the very low level of YTX that was detected in the heart muscle (Figs. 5 and 6, Tables 3 and 4). In this study, the concentration of toxins found in the internal organs of the mice was measured by LC-MS based on the method of Quilliam et al. (2001). This method has some limitations in that it has not been optimised for mouse tissues (Aasen et al., 2010). However, the method has been used for the analysis of several matrices in our lab, and was the best alternative available for quantification of low concentrations of AZA1 and YTX.

The LC-MS analysis could potentially be influenced by matrix effects from the different organs, but we were not able to study this phenomenon in the present work. However, since one of the major aims in this study was to compare the effects of different treatments on the concentration of YTX in the same organ, the possible matrix effects are likely to be minor. The ELISA method for YTX is expected to give higher figures than the LC-MS method if other analogues or metabolites of YTXs are present. With the LC-MS method, only YTX and two main analogues were measured, while with ELISA, all those YTX analogues that have an intact part of the ladder were measured (Briggs et al., 2004; Samdal et al., 2005). The 
results obtained with ELISA indicate that metabolism of YTX was generally modest, as the results were close to those obtained by LC-MS where YTX was the only analogue detected.

The limit of quantification (LOQ) for AZA1 with the LC-MS method was approximately 0.35 $\mathrm{ng} / \mathrm{mL}$ and for YTX $0.5 \mathrm{ng} / \mathrm{mL}$, while the limit of detection (LOD) was below $0.1 \mathrm{ng} / \mathrm{mL}$ for both toxins. The tissue samples were pooled from all animals treated, but the total weight was still relatively low for some of the organs. This low sample mass increases the uncertainty of the analysis, since the concentration in the extracts $(\mathrm{ng} / \mathrm{mL})$ was multiplied by extraction volume and divided by weights of the sampled organs to estimate the concentrations of toxins $(\mu \mathrm{g} / \mathrm{kg})$.

In conclusion, we report that oral exposure of mice to 1 or $5 \mathrm{mg} / \mathrm{kg}$ YTX, either alone or together with AZA1 at $200 \mu \mathrm{g} / \mathrm{kg}$ (a level that causes damage to the small intestine (Aasen et al., 2010)), does not lead to enhanced absorption of YTX nor to toxic effects in the heart or other internal organs. These results support the suggestion to deregulate YTXs in shellfish, especially since the most resent risk assessment by the EU Panel on Contaminants in the Food Chain (2008) recommend a considerably higher acute reference dose for the YTXgroup.

\section{Supporting Information}

Plot of ELISA (YTXs) versus LC/MS (YT

$X)$ results for tissues from mice dosed with YTX (1 and $5 \mathrm{mg} / \mathrm{kg})$ alone and in combination with AZA1 $(200 \mu \mathrm{g} / \mathrm{kg})$, with linear least squares correlations fitted in Excel.

\section{Acknowledgement}

We thank Nanna Bruun Sørensen and Lan Thi Tou Nguyen from the Norwegian School of Veterinary Science (NSVS) for help with extraction and analyses, Anne Kristine Fevang and Sissel Ansok at NSVS, for making histology sections, and Lene Hermansen, at NSVS for making electron microscopical specimens. We also than Adrian Smith at NSVS for help with gavaging the mice. The project was financed by the NFR project nr 172561/S40, and AZA1 was obtained through the ASTOX project at the Marine Institute, Ireland (project ST/02/02 of the Irish National Development Plan 2003-2006). The ELISA work and purification of YTX was supported by the New Zealand Foundation for Research, Science and Technology (International Investment Opportunities Fund, Grant C10X0406) and the BIOTOX project (partly funded by the European Commission, through 6th Framework Programme, Contract 514074, topic Food Quality and Safety). Also support from (Grant-Aid Agreement No PBA/AF/08/001(01)) under the Sea Change strategy with the support of the Marine Institute and the Marine Research Sub-Programme of the National Development Plan 2007-2013, co-financed under the European Regional Development Fund.

\section{Conflict of Interest}

On behalf of all authors I declare that there is no conflict of interest related to the publication of the manuscript. 


\section{References}

Aasen, J.A.B., Espenes, A., Hess, P., Aune, T., 2010. Sub-lethal dosing of azaspiracid in female NMRI mice. Toxicon 56, 1419-1425.

Amzil, Z., Sibat, M., Royer, F., Savar, V., 2008. First report on azaspiracid and yessotoxin groups detection in French shellfish. Toxicon 52, 39-48.

Aune, T., Aasen, J.A., Miles, C.O., Larsen, S., 2008. Effect of mouse strain and gender on $\mathrm{LD}_{50}$ of yessotoxin. Toxicon 52, 535-540.

Aune, T., Sorby, R., Yasumoto, T., Ramstad, H., Landsverk, T., 2002. Comparison of oral and intraperitoneal toxicity of yessotoxin towards mice. Toxicon 40, 77-82.

Briggs, L.R., Miles, C.O., Fitzgerald, J.M., Ross, K.M., Garthwaite, I., Towers, N.R., 2004. Enzyme-linked immunosorbent assay for the detection of yessotoxin and its analogues. Journal of Agricultural and Food Chemistry. 52, 5836-5842.

Callegari, F., Sosa, S., Ferrari, S., Soranzo, M.R., Pierotti, S., Yasumoto, T., Tubaro, A., Rossini, G.P., 2006. Oral administration of yessotoxin stabilizes E-cadherin in mouse colon. Toxicology 227, 145-155.

Ciminiello, P., Dell'Aversano, C., Fattorusso, E., Forino, M., Magno, S., Guerrini, F., Pistocchi, R., Boni, L., 2003. Complex yessotoxins profile in Protoceratium reticulatum from north-western Adriatic Sea revealed by LC-MS analysis. Toxicon 42, 7-14.

Draisci, R., Ferretti, E., Palleschi, L., Marchiafava, C., Poletti, R., Milandri, A., Ceredi, A., Pompei, M., 1999. High levels of yessotoxin in mussels and presence of yessotoxin and homoyessotoxin in dinoflagellates of the Adriatic Sea. Toxicon 37, 1187-1193.

EFSA, 2008. Opinion of the Scientific Panel on Contaminants in the Food chain on a request from the European Commission on marine biotoxins in shellfish - azaspiracids. The EFSA Journal 723, 1-52.

Espenes, A., Aasen, J.A.B., Hetland, D.L., Satake, M., Smith, A., Eraker, N., Aune, T., 2006. Toxicity of YTX in mice after repeated oral exposure. Henshilwood, K., Deegan, B., McMahon, T., Cusack, C, Keaveney, S., Silke, J., O'Cinneide, M., Lyons, D., and Hess, P. [Proceedings of the $5^{\text {th }}$ International Conference on Molluscan Shellfish Safety, Galway, Ireland, June $\left.14^{\text {th }}-18^{\text {th }},\right]$, Molluscan Shellfish Safety. 419-423.

FAO/IOC/WHO. 2004. Report of the Joint FAO/IOC/WHO ad hoc Expert Consultation on Biotoxins in Bivalve Molluscs. ftp://ftp.fao.org/es/esn/food/biotoxin_report_en.pdf

Hess, P., 2010. Requirements for screening and confirmatory methods for the detection and quantification of marine biotoxins in end-product and official control. Analytical and Bioanalytical Chemistry 397, 1683-1694.

Ito, E., Terao, K., 1994. Injury and recovery process of intestine caused by okadaic acid and related compounds. Natural Toxins 2, 371-377.

Ito, E., Yasumoto, T., Takai, A., Imanishi, S., Harada, K., 2002a. Investigation of the distribution and excretion of okadaic acid in mice using immunostaining method. Toxicon 40, 159-165.

Ito, E., Satake, M., Ofuji, K., Higashi, M., Harigaya, K., McMahon, T., Yasumoto, T., 2002b. Chronic effects in mice caused by oral administration of sublethal doses of azaspiracid, a new marine toxin isolated from mussels. Toxicon 40, 193-203.

Ito, E., Satake, M., Ofuji, K., Kurita, N., McMahon, T., James, K., Yasumoto, T., 2000. Multiple organ damage caused by a new toxin azaspiracid, isolated from mussels produced in Ireland. Toxicon 38, 917-930.

Loader, J.I., Hawkes, A.D., Beuzenberg, V., Jensen, D.J., Cooney, J.M., Wilkins, A.L., Fitzgerald, J.M., Briggs, L.R., Miles, C.O., 2007. Convenient large-scale purification of yessotoxin from Protoceratium reticulatum culture and isolation of a novel furanoyessotoxin. Journal of Agricultural and Food Chemistry. 55, 11093-11100. 
McMahon, T., Silke, J., 1996. Winter toxicity of unknown aetiology in mussels. Harmful Algae News 14, 2.

Munday, R. et. al., unpublished results.

Murata, M., Kumagai, M., Lee, J.S., Yasumoto, T., 1987. Isolation and structure of yessotoxin, a novel polyether compound implicated in diarrhetic shellfish poisoning. Tetrahedron Letters 28, 5869-5872.

NRC-CNRC. 2006. Certificate of analysis - NRC CRM-YTX, certified calibration solution for Yessotoxin. Institute for Marine Biosciences, Certified Reference Materials Programme. 9 pp.

NRC-CNRC. 2007. Certificate of analysis - NRC CRM-AZA1, certified calibration solution for Azaspiracid-1. Institute for Marine Biosciences, Certified Reference Materials Programme. 9 pp.

Ogino, H., Kumagai, M., Yasumoto, T., 1997. Toxicologic evaluation of yessotoxin. Natural Toxins 5, 255-259.

Paz, B., Daranas, A.H., Norte, M., Riobo, P., Franco, J.M., Fernandez, J.J., 2008. Yessotoxins, a group of marine polyether toxins: an overview. Marine Drugs 6, 73-102.

Perez, R., Rehmann, N., Crain, S., LeBlanc, P., Craft, C., MacKinnon, S., Reeves, K., Burton, I.W., Walter, J.A., Hess, P., Quilliam, M.A., Melanson, J.E., 2010. The preparation of certified calibration solutions for azaspiracid $1,-2$ and -3 , potent marine biotoxins found in shellfish. Analytical and Bioanalytical Chemistry 398, 2243-2252.

Quilliam, M.A., Hess, P., Dell'Aversano, C. 2001. Resent development in the analysis of phycotoxins by liquid chromatography-mass spectrometry. De Koe, W. J., Samson, R. A., van Egmond, H. P., Gilbert, J., and Sabino, M. Mycotoxins and Phycotoxins in perspective at the turn of the Millennium.Proceedings of the Xth International IUPAC Symposium on Mycotoxins and Phycotoxins., Brasil 2000. 383-391.

Rhodes, L., McNabb, P., de Salas, M., Briggs, L., Beuzenberg, V., Gladstone, M., 2006. Yessotoxin production by Gonyaulax spinifera. Harmful Algae 5, 148-155.

Roman, Y., Alfonso, A., Louzao, M.C., de la Rosa, L.A., Leira, F., Vieites, J.M., Vieytes, M.R., Ofuji, K., Satake, M., Yasumoto, T., Botana, L.M., 2002. Azaspiracid-1, a potent, nonapoptotic new phycotoxin with several cell targets. Cellular Signalling 14, 703-716.

Ronzitti, G., Hess, P., Rehmann, N., Rossini, G.P., 2007. Azaspiracid-1 alters the E-cadherin pool in epithelial cells. Toxicological Sciences 95, 427-435.

Ryan, G., Hess, P., Ryan, M. 2006. Development of a functional in vitro bioassay for azaspiracids (AZA) using human epithelial cells. Henshilwood, K., Deegan, B., McMahon, T., Cusack, C, Keaveney, S., Silke, J., O'Cinneide, M., Lyons, D., and Hess, P. [Proceedings of the $5^{\text {th }}$ International Conference on Molluscan Shellfish Safety, Galway, Ireland, June $14^{\text {th }}$ $18^{\text {th }}$, , Molluscan Shellfish Safety. 414-418.

Samdal, I.A., Naustvoll, L.J., Olseng, C.D., Briggs, L.R., Miles, C.O., 2004. Use of ELISA to identify Protoceratium reticulatum as a source of yessotoxin in Norway. Toxicon 44, 75-82.

Samdal, I.A., Aasen, J.A.B., Briggs, L.R., Dahl, E., Miles, C.O., 2005. Comparison of ELISA and LC-MS analyses for yessotoxins in blue mussels (Mytilus edulis). Toxicon 46, 7-15.

Satake, M., Ichimura, T., Sekiguchi, K., Yoshimatsu, S., Oshima, Y., 1999. Confirmation of yessotoxin and 45,46,47-trinoryessotoxin production by Protoceratium reticulatum collected in Japan. Natural Toxins 7, 147-150.

Satake, M., MacKenzie, L., Yasumoto, T., 1997. Identification of Protoceratium reticulatum as the biogenetic origin of yessotoxin. Natural Toxins 5, 164-167.

Terao, K., Ito, E., Oarada, M., Murata, M., Yasumoto, T., 1990. Histopathological studies on experimental marine toxin poisoning--5. The effects in mice of yessotoxin isolated from Patinopecten yessoensis and of a desulfated derivative. Toxicon 28, 1095-1104.

Terao, K., Ito, E., Yanagi, T., Yasumoto, T., 1986. Histopathological studies on experimental marine toxin poisoning. I. Ultrastructural changes in the small intestine and liver of suckling mice induced by dinophysistoxin-1 and pectenotoxin-1. Toxicon 24, 1141-1151.

Tubaro, A., Giangaspero, A., Ardizzone, M., Soranzo, M.R., Vita, F., Yasumoto, T., Maucher, J.M., Ramsdell, J.S., Sosa, S., 2008. Ultrastructural damage to heart tissue from repeated oral exposure to yessotoxin resolves in 3 months. Toxicon 51, 1225-1235. 
Tubaro, A., Sosa, S., Altinier, G., Soranzo, M.R., Satake, M., la Loggia, R., Yasumoto, T., 2004. Short-term oral toxicity of homoyessotoxins, yessotoxin and okadaic acid in mice. Toxicon 43, 439-445.

Tubaro, A., Sosa, S., Carbonatto, M., Altinier, G., Vita, F., Melato, M., Satake, M., Yasumoto, T., 2003. Oral and intraperitoneal acute toxicity studies of yessotoxin and homoyessotoxins in mice. Toxicon 41, 783-792.

Twiner, M.J., Hess, P., Dechraoui, M.Y., McMahon, T., Samons, M.S., Satake, M., Yasumoto, T., Ramsdell, J.S., Doucette, G.J., 2005. Cytotoxic and cytoskeletal effects of azaspiracid-1 on mammalian cell lines. Toxicon 45, 891-900.

Twiner, M.J., Rehmann, N., Hess, P., Doucette, G.J., 2008. Azaspiracid shellfish poisoning: A review on the chemistry, ecology, and toxicology with an emphasis on human health impacts. Marine Drugs 6, 39-72.

Ueoka, R., Ito, A., Izumikawa, M., Maeda, S., Takagi, M., Shin-Ya, K., Yoshida, M., van Soest, R.W.M., Matsunaga, S., 2009. Isolation of azaspiracid-2 from a marine sponge Echinoclathria sp as a potent cytotoxin. Toxicon 53, 680-684.

Yasumoto, T., Oshima, Y., Yamaguchi, M., 1978. Occurrence of a new type shellfish poisoning in the Tohoku district. Bulletin of the Japanese Society of Scientific Fisheries 44, 1249-1255.

\section{Figures}

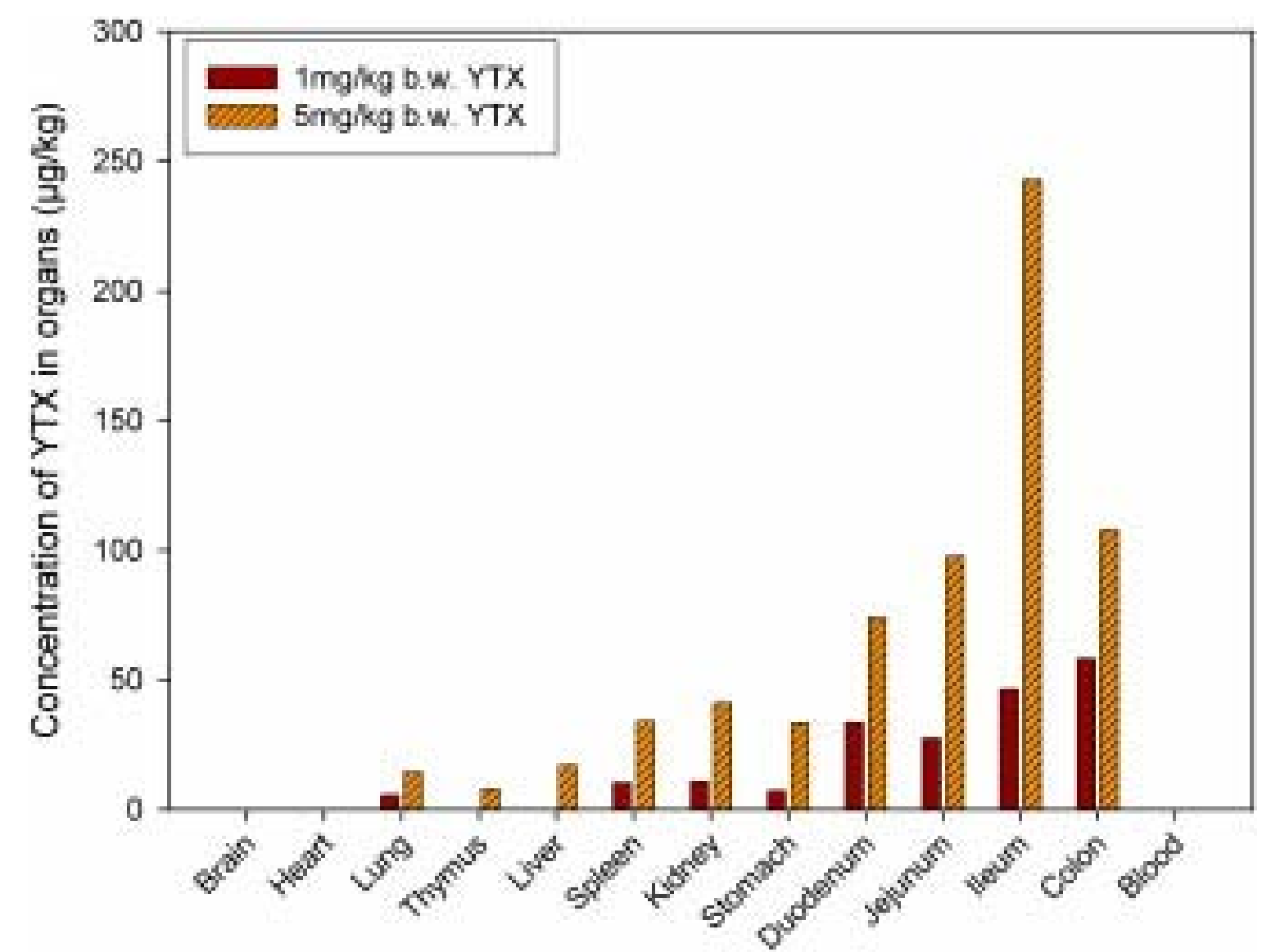

Figure 1. Concentrations of YTX (by LC/MS) in $\mu \mathrm{g} / \mathrm{kg}$ in tissues of female NMRI mice, after dosing $1 \mathrm{mg} / \mathrm{kg}$ and $5 \mathrm{mg} / \mathrm{kg}$ YTX by gavage. 


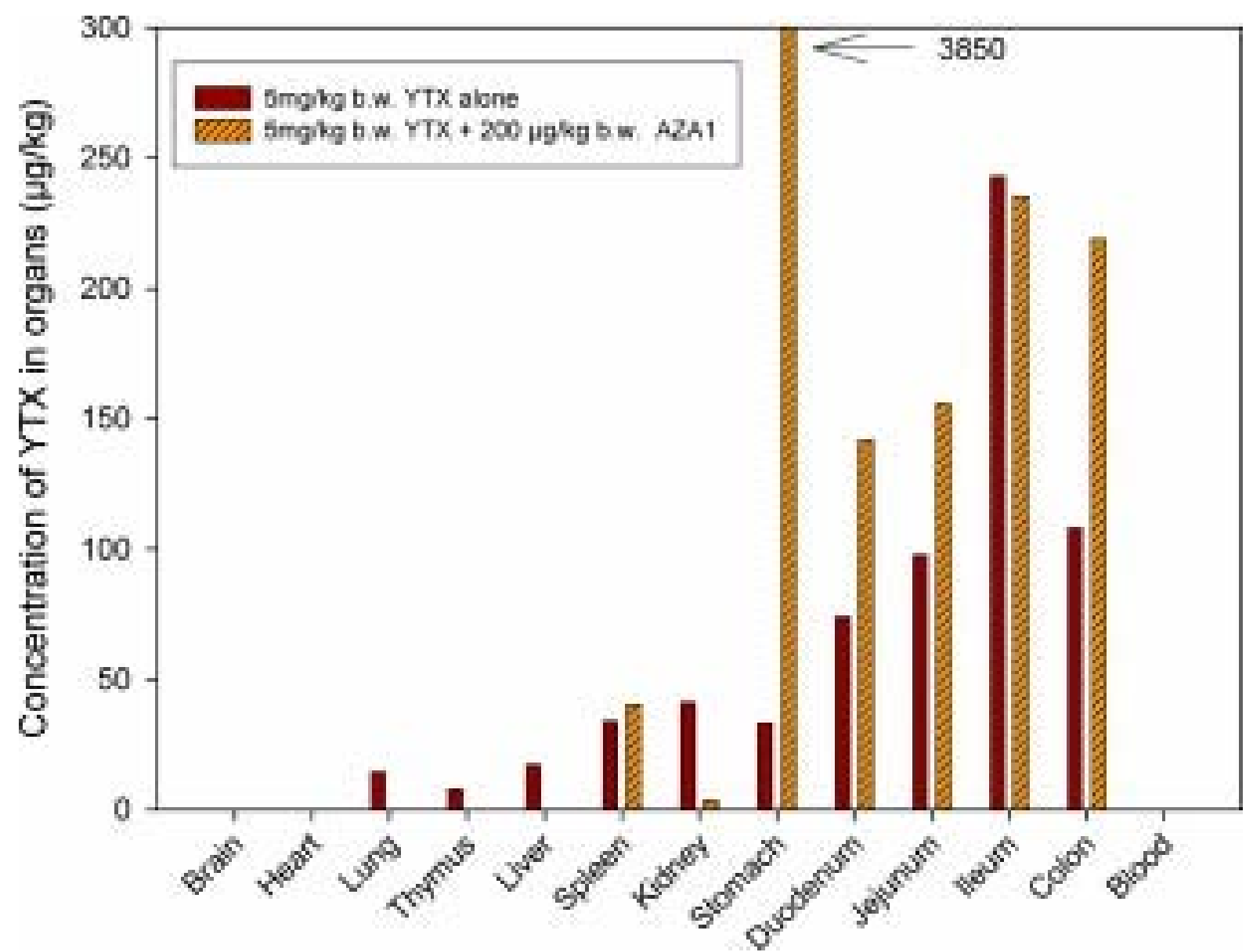

Figure 2. Concentrations of YTX (by LC/MS) in $\mu \mathrm{g} / \mathrm{kg}$ in tissues of female NMRI mice, when given alone at $5 \mathrm{mg} / \mathrm{kg}$ and in combination with $200 \mu \mathrm{g} / \mathrm{kg}$ AZA1. 


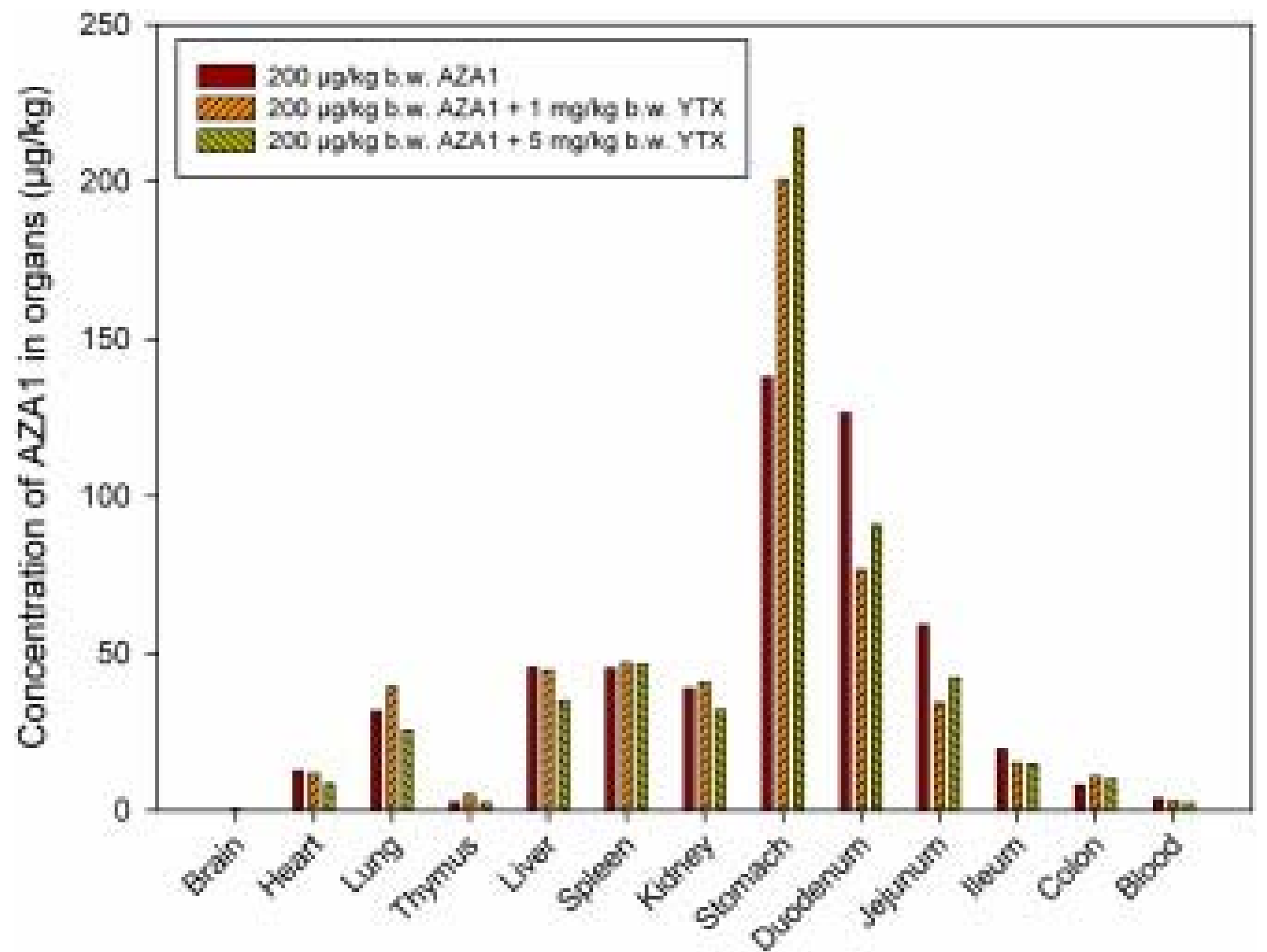

Figure 3. Concentrations of AZA1 in $\mu \mathrm{g} / \mathrm{kg}$ in tissues of female NMRI mice after dosing of $200 \mu \mathrm{g} / \mathrm{kg}$ AZA1 alone and in combination with $1 \mathrm{mg} / \mathrm{kg}$ and $5 \mathrm{mg} / \mathrm{kg}$ YTX. 

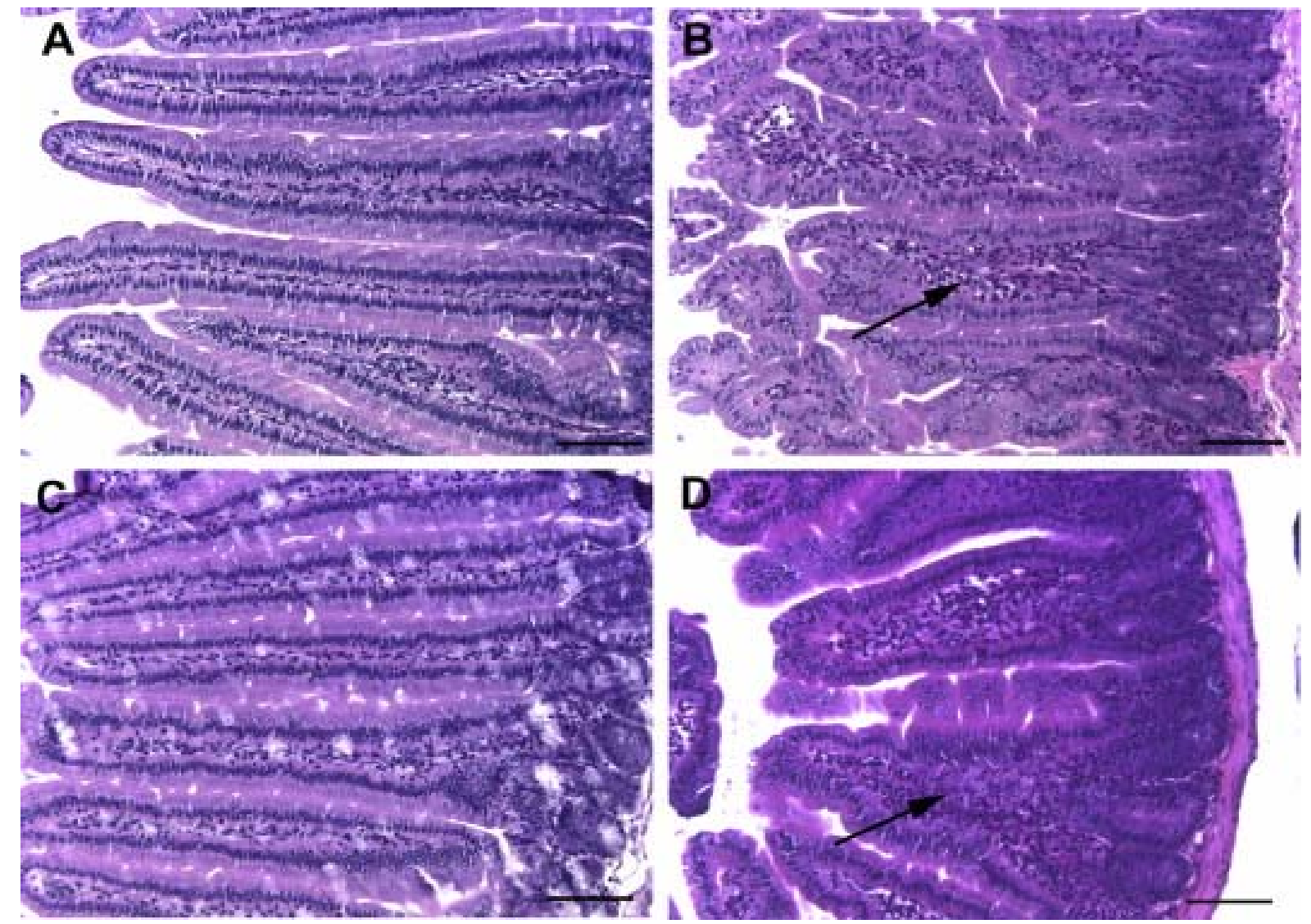

Figure 4. Representative micrographs of duodenum from mice killed $24 \mathrm{~h}$ after oral exposure to either (A) vehicle, (B) AZA1 alone, $200 \mu \mathrm{g} / \mathrm{kg}$, (C) YTX $5 \mathrm{mg} / \mathrm{kg}$ alone or (D) a combination of AZA1, $200 \mu \mathrm{g} / \mathrm{kg}$ and $Y T X, 5 \mathrm{mg} / \mathrm{kg}$. Mice exposed to AZA1 alone or the combination of AZA1 and YTX showed shortened villi, elongated crypts and accumulation of inflammatory cells in lamina propria (arrows). Mice exposed to YTX alone did not show changes. HE-stain. Bar: $100 \mu \mathrm{m}$. 

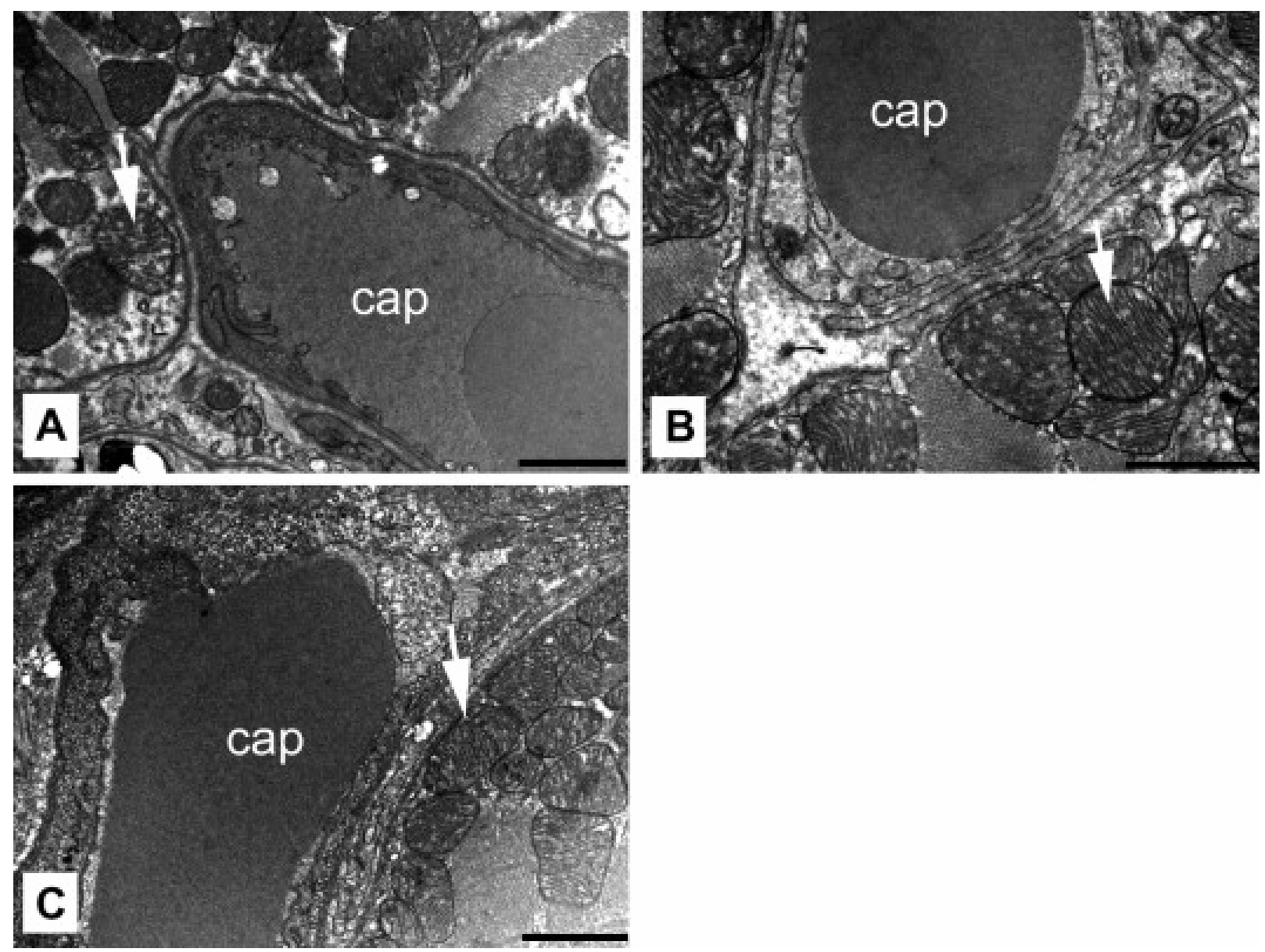

Figure 5. Representative electron micrographs of heart muscle of mice. Normal structure of capillaries (cap) and adjacent myocardial cells of a control is shown in A. There were no changes in myocardial cells close to the capillaries, either in mice orally exposed to YTX alone (B) or to a combination of AZA1, $200 \mu \mathrm{g} / \mathrm{kg}$ and YTX, $5 \mathrm{mg} / \mathrm{kg}$ (C). In all groups, the myocardial cells contained many mitochondria (arrows). Bar: $1 \mu \mathrm{m}$.
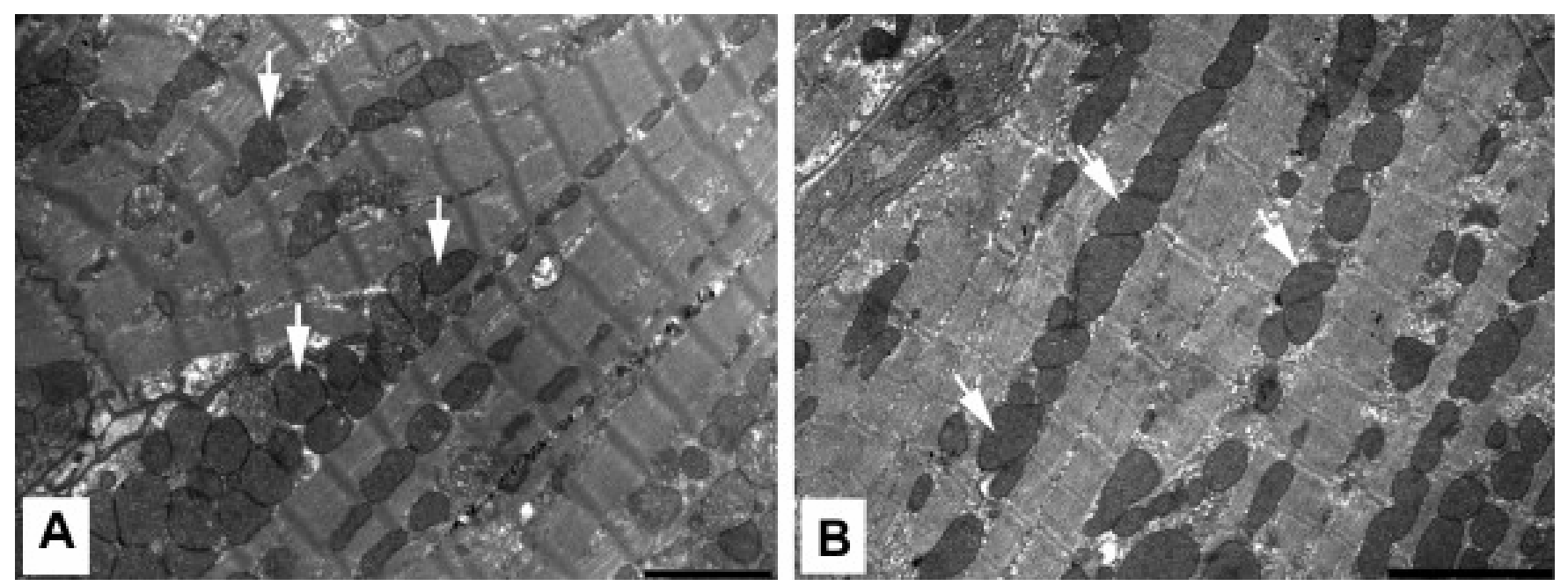

Figure 6. Electron micrographs of heart muscle. There were no changes in myocardial cells related to the structure of the myofibrils or the morphology or distribution of mitochondria (arrows) either in mice orally exposed to a combination of azaspiracid-1 at $200 \mu \mathrm{g} / \mathrm{kg}$ and yessotoxin at $5 \mathrm{mg} / \mathrm{kg}$ (B) nor as compared to mice exposed to vehicle only (A). Bar: $2 \mu \mathrm{m}$. 


\section{Tables}

\begin{tabular}{|l|l|l|l|l|}
\hline Group & EtOH $(\boldsymbol{\mu L})$ & Saline $(\boldsymbol{\mu L})$ & AZA stock $(\boldsymbol{\mu L})$ & YTX stock $(\boldsymbol{\mu L})$ \\
\hline Control & 80 & 1920 & 0 & 0 \\
\hline AZA1 & 40 & 960 & 393 & 0 \\
\hline AZA1 + 1 mg YTX & 40 & 960 & 393 & 40 \\
\hline AZA1 + 5 mg YTX & 40 & 960 & 393 & 200 \\
\hline 1 mg YTX & 40 & 960 & 0 & 40 \\
\hline 5 mg YTX & 40 & 960 & 0 & 200 \\
\hline
\end{tabular}

Table 1. Calculated volumes of AZA1 and YTX stock solutions for dilutions

\begin{tabular}{|l|l|l|l|l|l|l|l|}
\hline Time $(\mathrm{min})$ & 0 & 8 & 15 & 15.5 & 20.5 & 21 & 30 \\
\hline Flow $(\mu \mathrm{L} / \mathrm{min})$ & 200 & 200 & 200 & 400 & 400 & 200 & 200 \\
\hline$\% \mathrm{~B}$ & 30 & 90 & 90 & 100 & 100 & 30 & 30 \\
\hline
\end{tabular}

Table 2. HPLC gradient program with two-phase gradient of water (A) and 95\% acetonitrile (B), each containing $50 \mathrm{mM}$ formic acid and $2 \mathrm{mM}$ ammonium formate 


\begin{tabular}{|c|c|c|c|c|c|c|c|c|c|c|c|c|c|c|c|c|}
\hline Method & \multicolumn{8}{|c|}{ LC-MS/MS } & \multicolumn{8}{|l|}{ ELISA } \\
\hline $\begin{array}{l}\text { Toxin } \\
\text { combination }\end{array}$ & \multicolumn{4}{|c|}{ YTX alone } & \multicolumn{4}{|c|}{ YTX and AZA1 } & \multicolumn{4}{|c|}{ YTX alone } & \multicolumn{4}{|c|}{ YTX and AZA1 } \\
\hline Dose & \multicolumn{2}{|l|}{$1 \mathrm{mg}$} & \multicolumn{2}{|l|}{$5 \mathrm{mg}$} & \multicolumn{2}{|l|}{$1 \mathrm{mg}$} & \multicolumn{2}{|l|}{$5 \mathrm{mg}$} & \multicolumn{2}{|l|}{$1 \mathrm{mg}$} & \multicolumn{2}{|l|}{$5 \mathrm{mg}$} & \multicolumn{2}{|l|}{$1 \mathrm{mg}$} & \multicolumn{2}{|l|}{$5 \mathrm{mg}$} \\
\hline & & LOQ & & LOQ & & LOQ & & LOQ & & LOQ & & LOQ & & LOQ & & LOQ \\
\hline Blood & $<\mathrm{LOQ}$ & 3 & $<\mathrm{LOQ}$ & 3 & $<\mathrm{LOQ}$ & 4 & 3 & 3 & 4 & 0.6 & 8 & 0.6 & 7 & 0.7 & 12 & 0.7 \\
\hline Brain & $<\mathrm{LOQ}$ & 2 & $<\mathrm{LOQ}$ & 2 & $<\mathrm{LOQ}$ & 2 & $<\mathrm{LOQ}$ & 2 & $<\mathrm{LOQ}$ & 0.8 & 8 & 0.8 & $<\mathrm{LOQ}$ & 0.6 & $<\mathrm{LOQ}$ & 0.8 \\
\hline Heart & $<$ LOQ & 13 & $<\mathrm{LOQ}$ & 17 & $<$ LOQ & 18 & $<\mathrm{LOQ}$ & 14 & $<$ LOQ & 0.7 & 24 & 0.7 & $<$ LOQ & 0.7 & $<\mathrm{LOQ}$ & 0.7 \\
\hline Lung & 6 & 5 & 15 & 7 & 62 & 5 & $<$ LOQ & 6 & 16 & 0.7 & 35 & 0.7 & 79 & 0.7 & 9 & 0.7 \\
\hline Thymus & $<\mathrm{LOQ}$ & 4 & 8 & 6 & $<\mathrm{LOQ}$ & 5 & $<\mathrm{LOQ}$ & 9 & $<\mathrm{LOQ}$ & 0.7 & $<\mathrm{LOQ}$ & 0.7 & $<\mathrm{LOQ}$ & 0.7 & $<\mathrm{LOQ}$ & 0.7 \\
\hline Liver & $<\mathrm{LOQ}$ & 2 & 17 & 2 & 3 & 2 & $<\mathrm{LOQ}$ & 2 & 20 & 0.7 & 41 & 0.7 & 9 & 0.7 & 23 & 0.7 \\
\hline Spleen & 10 & 7 & 34 & 6 & $<$ LOQ & 6 & 40 & 8 & 41 & 0.6 & 66 & 0.6 & 17 & 0.7 & 120 & 0.7 \\
\hline Kidney & 11 & 3 & 41 & 3 & $<\mathrm{LOQ}$ & 3 & 4 & 3 & 125 & 0.6 & 214 & 0.6 & 40 & 0.7 & 93 & 0.7 \\
\hline Stomach & 7 & 2 & 33 & 2 & 663 & 2 & 3851 & 2 & 15 & 0.8 & 69 & 0.8 & 826 & 0.6 & 4331 & 0.8 \\
\hline Duodenum & 33 & 3 & 74 & 4 & 44 & 4 & 142 & 4 & 49 & 0.7 & 109 & 0.8 & 70 & 0.7 & 191 & 0.7 \\
\hline Jejunum & 27 & 5 & 98 & 5 & 58 & 4 & 156 & 4 & 33 & 0.6 & 134 & 0.8 & 88 & 0.6 & 177 & 0.6 \\
\hline Ileum & 46 & 7 & 243 & 5 & 60 & 8 & 235 & 6 & 70 & 0.8 & 394 & 0.8 & 108 & 0.8 & 322 & 0.8 \\
\hline Colon & 58 & 4 & 108 & 4 & 85 & 5 & 219 & 6 & 111 & 0.6 & 150 & 0.6 & 143 & 0.7 & 454 & 0.7 \\
\hline
\end{tabular}


Table 3. Levels of YTX $(\mu \mathrm{g} / \mathrm{kg})$ found by LC-MS/MS and by ELISA in mouse tissues. LOQ values for each sample given

\begin{tabular}{|c|c|c|c|c|c|c|c|}
\hline \multicolumn{8}{|c|}{ Doses of YTX given by oral intubation } \\
\hline \multirow[b]{2}{*}{ Organ } & \multirow[b]{2}{*}{$\begin{array}{l}\text { Average organ } \\
\text { weight in (g) } \\
\text { adjusted for } 20 \mathrm{~g} \\
\text { mouse }\end{array}$} & \multicolumn{3}{|l|}{$1 \mathrm{mg} / \mathrm{kg}$} & \multicolumn{3}{|l|}{$5 \mathrm{mg} / \mathrm{kg}$} \\
\hline & & $\begin{array}{l}\text { Total toxin } \\
\text { in organ } \\
\text { (ng) }\end{array}$ & $\begin{array}{l}\% \text { of } \\
\text { dose }\end{array}$ & $\begin{array}{l}\text { LOQ } \\
\text { (ng) }\end{array}$ & $\begin{array}{l}\text { Total toxin } \\
\text { in organ } \\
\text { (ng) }\end{array}$ & $\begin{array}{l}\% \text { of } \\
\text { dose }\end{array}$ & $\begin{array}{l}\text { LOQ } \\
\text { (ng) }\end{array}$ \\
\hline \multicolumn{8}{|c|}{ YTX alone } \\
\hline Heart & 0.099 & $<\mathrm{LOQ}$ & n.a & 1.3 & $<\mathrm{LOQ}$ & n.a & 1.7 \\
\hline Liver & 0.967 & $<\mathrm{LOQ}$ & n.a & 1.9 & 16.6 & 0.02 & 1.9 \\
\hline Spleen & 0.119 & 1.2 & 0.006 & 0.9 & 4.1 & 0.004 & 0.7 \\
\hline Kidney & 0.253 & 2.8 & 0.01 & 0.7 & 10.4 & 0.01 & 0.7 \\
\hline Lung & 0.165 & 1.0 & 0.005 & 0.8 & 2.4 & 0.002 & 1.2 \\
\hline Brain & 0.483 & $<\mathrm{LOQ}$ & n.a & 0.9 & $<\mathrm{LOQ}$ & n.a & 0.9 \\
\hline \multicolumn{8}{|c|}{ YTX with $200 \mu \mathrm{g} / \mathrm{kg}$ AZA1 } \\
\hline Heart & 0.099 & $<\mathrm{LOQ}$ & n.a & 1.7 & $<\mathrm{LOQ}$ & n.a & 1.4 \\
\hline Liver & 0.967 & 2.5 & 0.01 & 1.7 & $<\mathrm{LOQ}$ & n.a & 1.9 \\
\hline Spleen & 0.119 & $<\mathrm{LOQ}$ & n.a & 0.8 & 4.8 & 0.005 & 0.9 \\
\hline Kidney & 0.253 & $<$ LOQ & n.a & 0.6 & 0.9 & $9 \times 10^{-4}$ & 0.7 \\
\hline Lung & 0.165 & 10.3 & 0.05 & 0.8 & $<\mathrm{LOQ}$ & n.a & 1.0 \\
\hline Brain & 0.483 & $<\mathrm{LOQ}$ & n.a & 1.0 & $<\mathrm{LOQ}$ & n.a & 0.8 \\
\hline
\end{tabular}

Table 4: Average weight of internal organs of $20 \mathrm{~g}$ female NMRI mice and estimates of total amount of YTX (ng) determined by LCMS in internal organs of mice $24 \mathrm{~h}$ after oral intubation at two doses, with and without AZA1 $(200 \mu \mathrm{g} / \mathrm{kg})$, and estimated percentage of dosed YTX recovered in each organ. LOQ in ng for each organ in separate column. 